\title{
Hidden MHC genetic diversity in the Iberian ibex (Capra pyrenaica)
}

Samer Angelone ${ }^{1,2^{*}}$ (D) Michael J. Jowers ${ }^{3}$, Anna Rita Molinar Min ${ }^{4}$, Paulino Fandos ${ }^{5}$, Paloma Prieto ${ }^{6}$, Mario Pasquetti ${ }^{4}$, Francisco Javier Cano-Manuel ${ }^{7}$, Gregorio Mentaberre ${ }^{8}$, Jorge Ramón López Olvera ${ }^{8}$, Arián Ráez-Bravo ${ }^{8}$, José Espinosa ${ }^{9}$, Jesús M. Pérez ${ }^{9}$, Ramón C. Soriguer ${ }^{1}$, Luca Rossi ${ }^{4}$ and José Enrique Granados ${ }^{7}$

\begin{abstract}
Background: Defining hidden genetic diversity within species is of great significance when attempting to maintain the evolutionary potential of natural populations and conduct appropriate management. Our hypothesis is that isolated (and eventually small) wild animal populations hide unexpected genetic diversity due to their maintenance of ancient polymorphisms or introgressions.

Results: We tested this hypothesis using the Iberian ibex (Capra pyrenaica) as an example. Previous studies based on large sample sizes taken from its principal populations have revealed that the Iberian ibex has a remarkably small MHC DRB1 diversity (only six remnant alleles) as a result of recent population bottlenecks and a marked demographic decline that has led to the extinction of two recognized subspecies. Extending on the geographic range to include non-studied isolated Iberian ibex populations, we sequenced a new MHC DRB1 in what seemed three small isolated populations in Southern Spain $(n=132)$. The findings indicate a higher genetic diversity than previously reported in this important gene. The newly discovered allele, MHC DRB1*7, is identical to one reported in the domestic goat $C$. aegagrus hircus. Whether or not this is the result of ancient polymorphisms maintained by balancing selection or, alternatively, introgressions from domestic goats through hybridization needs to be clarified in future studies. However, hybridization between Iberian ibex and domestic goats has been reported in Spain and the fact that the newly discovered allele is only present in one of the small isolated populations and not in the others suggests introgression. The new discovered allele is not expected to increase fitness in C. pyrenaica since it generates the same protein as the existing MHC DRB1*6. Analysis of a microsatellite locus (OLADRB1) near the new MHC DRB1*7 gene reveals a linkage disequilibrium between these two loci. The allele OLADRB1, 187 bp in length, was unambiguously linked to the MHC DRB1*7 allele. This enabled us to perform a DRB-STR matching method for the recently discovered $\mathrm{MHC}$ allele.
\end{abstract}

Conclusions: This finding is critical for the conservation of the Iberian ibex since it directly affects the identification of the units of this species that should be managed and conserved separately (Evolutionarily Significant Units).

Keywords: Capra pyrenaica hispanica, Capra pyrenaica victoriae, Capra aegagrus hircus, Major histocompatibility complex (MHC), MHC DRB1, OLADRB1, Linkage disequilibrium, DRB-STR method, Sierras de Cazorla, Segura and las Villas Natural Park, Spain

\footnotetext{
* Correspondence: sameralasaad@hotmail.com

${ }^{1}$ Estación Biológica de Doñana, Consejo Superior de Investigaciones

Científicas (CSIC), Avda. Américo Vespucio s/n, 41092 Sevilla, Spain

${ }^{2}$ Institute of Evolutionary Biology and Environmental Studies (IEU), University

of Zurich, Winterthurerstrasse 190, Zurich, Switzerland

Full list of author information is available at the end of the article
}

(c) The Author(s). 2018 Open Access This article is distributed under the terms of the Creative Commons Attribution 4.0 International License (http://creativecommons.org/licenses/by/4.0/), which permits unrestricted use, distribution, and reproduction in any medium, provided you give appropriate credit to the original author(s) and the source, provide a link to the Creative Commons license, and indicate if changes were made. The Creative Commons Public Domain Dedication waiver (http://creativecommons.org/publicdomain/zero/1.0/) applies to the data made available in this article, unless otherwise stated. 


\section{Background}

Hidden genetic diversity, that is, unreported allelic diversity in already studied species or populations, is of great significance in the maintaining of the evolutionary potential of natural populations and the execution of appropriate management methods [1]. Cryptic genetic diversity is critical in conservation biology since it directly affects the identification of the units of species that need to be managed and conserved separately (Evolutionarily Significant Units, ESU) [2].

The major histocompatibility complex (MHC) plays a key part in the recognition of foreign antigen and the immune response to pathogens and parasites in vertebrates [3]. For this reason, $\mathrm{MHC}$ and immune gene variation are regarded as a barometer for the genetic health of wild populations [4]. High levels of allelic diversity have been found in $\mathrm{MHC}$ genes [5], which makes these closely linked genes some of the most polymorphic regions in the whole vertebrate genome [6]. Host-parasite co-evolution is assumed to maintain this level of polymorphism in the MHC loci [7], even though the molecular mechanisms involved in maintaining such extraordinary MHC polymorphism in vertebrates are still debated by epidemiologists, immunogeneticists and evolutionary biologists alike [8]. Nevertheless, many endangered and currently non-endangered species such as Arabian oryx (Oryx leucoryx), muskox (Ovibos moschatus), moose (Alces alces), fallow deer (Dama dama), beaver (Castor fiber), Asiatic lion (Panthera leo persica), cotton-top tamarin (Saguinus oedipus), cheetah (Acinonyx jubatus) and Tasmanian devil (Sarcophilus harrisii) all exhibit reduced allelic variation or even monomorphism at the MHC loci caused mainly by severe population bottlenecks [9-16].

Additionally, the well-known limited MHC variability in wild goats (genus Capra) may be related to its northerly distribution since allelic diversity at $\mathrm{MHC}$ DRB class II in wild ungulates decreases with increasing latitude, possibly either as a result of lower parasite diversity at high latitudes [9], proximity to the limit of the species' range, and/or bottleneck effects provoked by recent declines in population size [17]. The low MHC variability in wild goats (genus Capra) potentially exposes their populations to collapse due either, among other stochastic events, to the introduction of pathogens or northward distribution shifts of pathogens triggered by climate warming [18].

Four subspecies of Iberian ibex are officially recognized $[19,20]$, of which two (C. $p$. pyrenaica and $C$. $p$. lusitanica) have recently become extinct. The surviving subspecies (C. p. hispanica and $C . p$. victoriae) have an allopatric distribution in the Iberian Peninsula [21]. Previous studies centred on the few main Iberian ibex populations have revealed that this ibex has remarkably low genetic variation at the class II MHC DRB1 gene, with only six different DRB1 alleles [22-24]. One of the alleles (MHC DRB1*4) became extinct with the extinction of the subspecies $C$. $p$. pyrenaica. The limited allelic variability of the DRB1 gene in the Iberian ibex is likely to be the direct result of its recent history of population bottlenecks and severe demographic decline $[25,26]$.

Our hypothesis is that small and isolated wild animal populations hide unexpected genetic diversity due to the maintenance of ancient polymorphisms or introgressions. Small and isolated population are much more exposed to introgression scenarios as a result of hybridization with domestic animals [26]. The aim of the present study was to test this hypothesis using the Iberian ibex as an example. We extended the sampling size to include small isolated populations ignored by previous studies. If our hypothesis (new MHC DRB1 alleles) is true, we will need to develop a simple and relatively inexpensive protocol for genotyping the newly discovered alleles. The method described by Alasaad et al. [23] is based on linkage disequilibrium analysis of a microsatellites locus (OLADRB1) and the MHC DRB1 gene. The OLADRB1 is located close to the MHC DRB1 gene [27] and hence the allele length polymorphism at OLADRB1 is usually unambiguously linked to a particular DRB1 allele; thus, sequencing the MHC DRB1 gene is not necessary.

\section{Methods}

\section{Sample collection and DNA extraction}

We collected 132 Iberian ibex samples from several Spanish populations of the surviving recognized subspecies, C. p. hispanica and C. p. victoria, in 2014-2016 (Tables 1 and 2, and Fig. 1). These samples consisted of tissue obtained from legally hunted, naturally deceased or anesthetized animals. Tissue samples were stored in $70 \%$ ethanol at $-20{ }^{\circ} \mathrm{C}$ before genomic DNA extraction with a commercial kit (NucleoSpin ${ }^{\otimes}$ Tissue; QIAGEN) following the manufacturer's protocol.

PCR amplification and sequencing of the MHC DRB1 gene The second exon of the DRB1 gene was sequenced using a semi-nested PCR as previously reported [28]. The PCR reaction mixture for PCR I (pre-amplification) consisted of $2 \mu \mathrm{L}(25-50 \mathrm{ng} / \mu \mathrm{l})$ of gDNA, $0.25 \mu \mathrm{M}$ of each primer (using primer pairs DRB1.1 and GIo, [29]), $0.217 \mu \mathrm{M}$ dNTP's, $1 \times$ buffer (QIAGEN), and $0.1 \mu \mathrm{L}$ Taq Polymerase $(5 \mathrm{U} / \mu \mathrm{L})$ (Hot-Start Taq DNA polymerase, QIAGEN) in a final volume of $10 \mu \mathrm{L}$. The samples were subjected to the following thermal profile for amplification in a 2720 Thermal Cycler (Applied Biosystems, Foster City, California): $15 \mathrm{~min}$ at $95{ }^{\circ} \mathrm{C}$ (initial denaturing), followed by 10 cycles of three steps of $1 \mathrm{~min}$ at $94{ }^{\circ} \mathrm{C}$ (denaturation), $1 \mathrm{~min}$ at $60{ }^{\circ} \mathrm{C}$ (annealing) and $90 \mathrm{~s}$ at $72{ }^{\circ} \mathrm{C}$ (extension), before a final elongation of $5 \mathrm{~min}$ at $72{ }^{\circ} \mathrm{C}$. PCR blanks (reagents only) were included. We used 


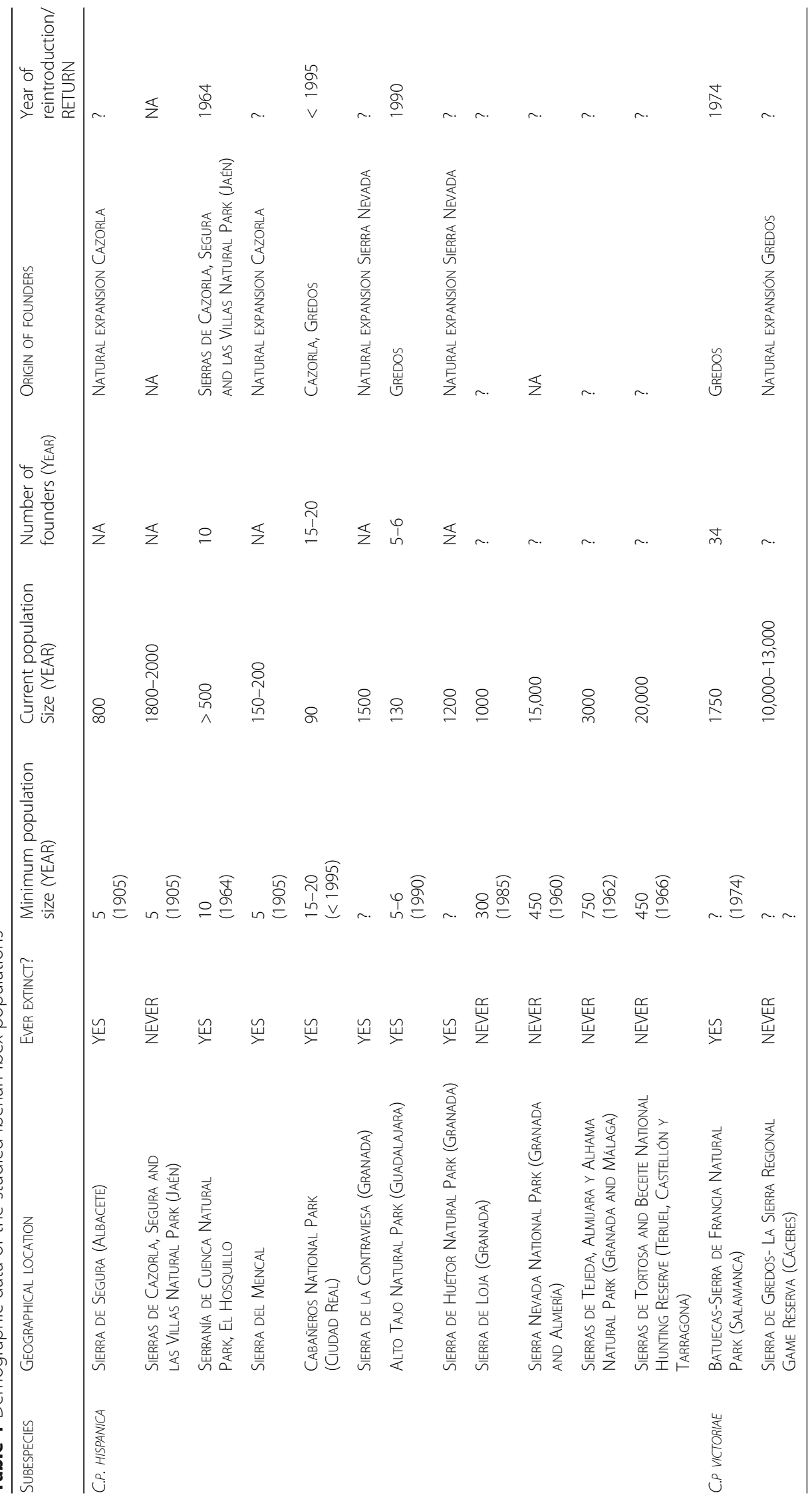


Table 2 DRB1 gene and associated OLADRB1 microsatellite alleles of the Iberian ibex samples obtained from each geographical location in Spain

\begin{tabular}{|c|c|c|c|c|c|}
\hline Sub-species & Geographical location & Sample size & MHC DRB1 locus & OLADRB1 & $\begin{array}{l}\text { MHC DRB1 and } \\
\text { OLADRB frequency } \\
\text { (from the total) } \%\end{array}$ \\
\hline \multirow[t]{28}{*}{ C.p. hispanica } & \multirow[t]{3}{*}{ Sierra de Segura (Albacete) } & \multirow[t]{3}{*}{3} & $\mathrm{DRB} 1^{* 1}$ & 169 & 66.67 \\
\hline & & & $\mathrm{DRB} 1 * 2$ & 159 & 16.67 \\
\hline & & & $\mathrm{DRB} 1 * 5$ & 172 & 16.67 \\
\hline & \multirow[t]{3}{*}{ Sierras de Cazorla, Segura and las Villas Natural Park (Jaén) } & \multirow[t]{3}{*}{24} & $\mathrm{DRB} 1^{* 1}$ & 169 & 64.58 \\
\hline & & & $\mathrm{DRB} 1 * 5$ & 172 & 4.17 \\
\hline & & & $\mathrm{DRB} 1 * 7$ & 189 & 31.25 \\
\hline & \multirow{2}{*}{$\begin{array}{l}\text { Serranía de Cuenca Natural Park, El Hosquillo (originally } \\
\text { from Cazorla) }\end{array}$} & \multirow[t]{2}{*}{5} & $\mathrm{DRB} 1^{* 1}$ & 169 & 80 \\
\hline & & & $\mathrm{DRB} 1 * 7$ & 189 & 20 \\
\hline & \multirow[t]{2}{*}{ Sierra del Mencal (Granada) } & \multirow[t]{2}{*}{1} & $\mathrm{DRB} 1 * 5$ & 172 & 50 \\
\hline & & & $\mathrm{DRB} 1 * 7$ & 189 & 50 \\
\hline & \multirow{2}{*}{$\begin{array}{l}\text { Cabañeros National Park (Ciudad Real) (originally from } \\
\text { different populations including Cazorla) }\end{array}$} & \multirow[t]{2}{*}{3} & $\mathrm{DRB} 1^{* 1}$ & 169 & 83.33 \\
\hline & & & $\mathrm{DRB} 1 * 7$ & 189 & 16.67 \\
\hline & \multirow[t]{2}{*}{ Sierra de la Contraviesa (Granada) } & \multirow[t]{2}{*}{1} & $\mathrm{DRB} 1^{* 1}$ & 169 & 50 \\
\hline & & & $\mathrm{DRB} 1 * 3$ & 187 & 50 \\
\hline & \multirow[t]{2}{*}{ Alto Tajo Natural Park (Guadalajara) } & \multirow[t]{2}{*}{5} & $\mathrm{DRB} 1^{* 1}$ & 169 & 50 \\
\hline & & & $\mathrm{DRB} 1 * 2$ & 159 & 50 \\
\hline & \multirow[t]{2}{*}{ Sierra de Huétor Natural Park (Granada) } & \multirow[t]{2}{*}{1} & $\mathrm{DRB} 1^{* 1}$ & 169 & 50 \\
\hline & & & $\mathrm{DRB} 1 * 6$ & 185 & 50 \\
\hline & Sierra de Loja (Granada) & 9 & $\mathrm{DRB} 1 * 5$ & 172 & 100 \\
\hline & \multirow[t]{4}{*}{ Sierra Nevada National Park (Granada and Almería) } & \multirow[t]{4}{*}{25} & $\mathrm{DRB} 1 * 1$ & 169 & 24 \\
\hline & & & $\mathrm{DRB} 1 * 2$ & 159 & 36 \\
\hline & & & $\mathrm{DRB} 1 * 5$ & 172 & 26 \\
\hline & & & $\mathrm{DRB} 1 * 6$ & 185 & 14 \\
\hline & \multirow{3}{*}{$\begin{array}{l}\text { Sierras de Tejeda, Almijara y Alhama Natural Park (Granada } \\
\text { and Málaga) }\end{array}$} & \multirow[t]{3}{*}{11} & $\mathrm{DRB} 1^{* 1}$ & 169 & 40.9 \\
\hline & & & $\mathrm{DRB} 1 * 5$ & 172 & 45.45 \\
\hline & & & DRB1*6 & 185 & 13.64 \\
\hline & \multirow{2}{*}{$\begin{array}{l}\text { Puertos de Tortosa and Beceite National Hunting Reserve } \\
\text { (Tarragona) }\end{array}$} & \multirow[t]{2}{*}{20} & $\mathrm{DRB} 1 * 2$ & 159 & 42.5 \\
\hline & & & $\mathrm{DRB} 1 * 3$ & 187 & 57.5 \\
\hline \multirow[t]{7}{*}{ C. p. victoriae } & \multirow{3}{*}{$\begin{array}{l}\text { Batuecas-Sierra de Francia Natural Park (Salamanca) } \\
\text { (originally from Gredos) }\end{array}$} & \multirow[t]{3}{*}{16} & $\mathrm{DRB} 1 * 1$ & 169 & 31.25 \\
\hline & & & $\mathrm{DRB} 1 * 2$ & 159 & 53.13 \\
\hline & & & $\mathrm{DRB} 1 * 6$ & 185 & 15.62 \\
\hline & \multirow[t]{4}{*}{ "La Sierra" Regional Game Reserve (Cáceres) } & \multirow[t]{4}{*}{8} & $\mathrm{DRB} 1^{* 1}$ & 169 & 43.57 \\
\hline & & & $\mathrm{DRB} 1 * 2$ & 159 & 43.57 \\
\hline & & & DRB1*3 & 187 & 6.25 \\
\hline & & & DRB 1*6 & 185 & 6.25 \\
\hline
\end{tabular}

$2 \mu \mathrm{L}$ of the PCR-product of PCR I as a template for PCR II (semi-nested with primers DRB1.1 and DRB1.2) [29]. We employed the same PCR reaction mixture and thermal profile as in PCR I but with an annealing temperature of $65{ }^{\circ} \mathrm{C}$ and 25 (instead of 10) cycles. PCR blanks (reagents only) were included as before.
Templates of the PCR II were analyzed by Macrogene Europe Laboratories (EZ-Seq service) for sequencing. DNA sequences were aligned and edited using the software BioEdit v.7.0.9 [30]. Allele inference from heterozygous sequences was carried out with the program PHASE [31]. 


\section{Genetic samples of Capra pyrenaica}

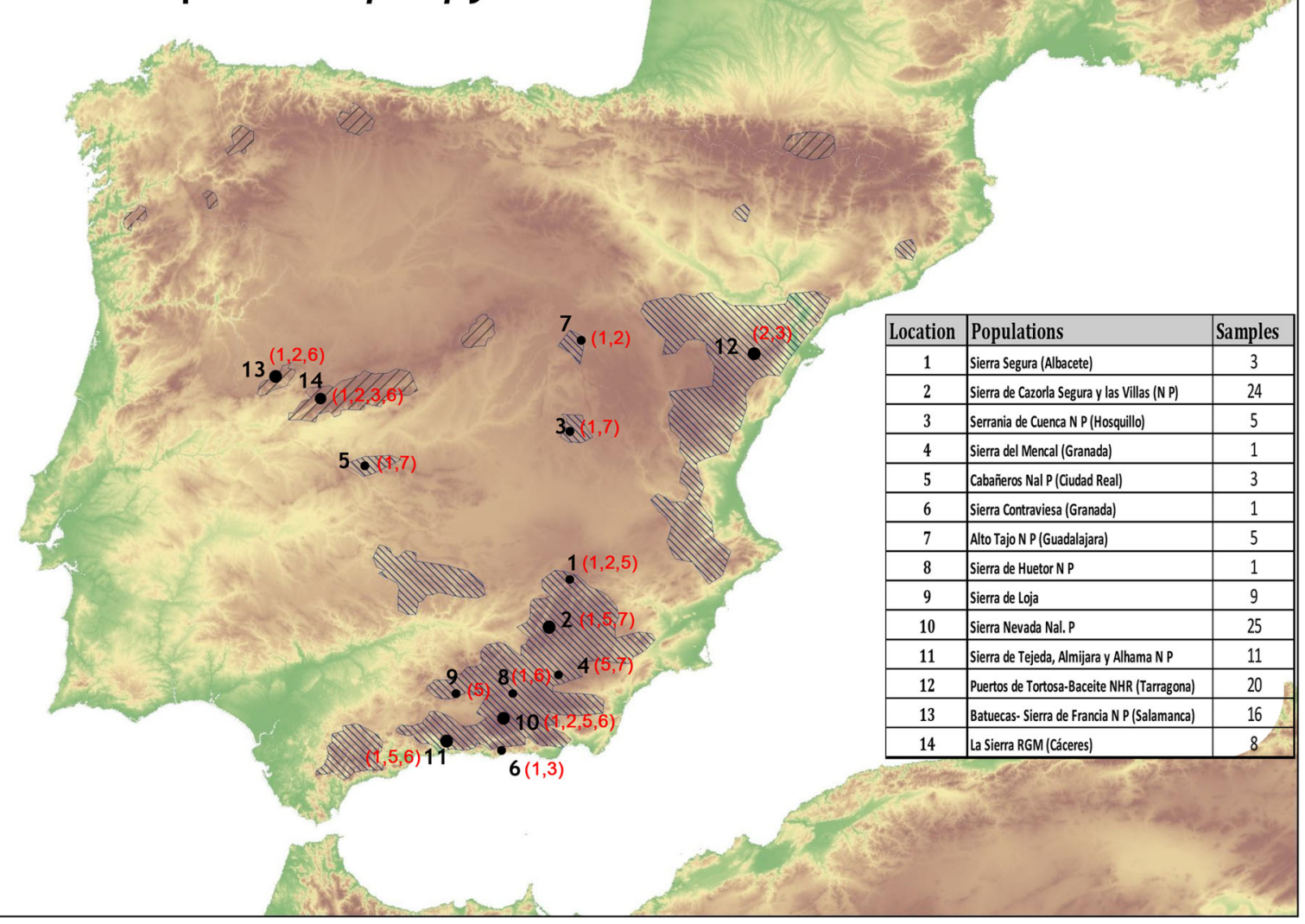

Fig. 1 Map of the Iberian Peninsula showing the current Iberian ibex (Capra pyrenaica) distribution and the location of the studied populations. The MHC DRB1alleles are shown in red (DRB $1^{*} 1=1, \mathrm{DRB}^{*} 2=2, \mathrm{DRB} 1 * 3=3, \mathrm{DRB} 1 * 5=5, \mathrm{DRB} 1 * 6=6$, and $\mathrm{DRB} 1 * 7=7$ ). The populations in the Sierra Nevada National Park (10), Puertos de Tortosa and Beceite National Hunting Reserve (12), and Batuecas-Sierra de Francia Natural Park (13) have previously been studied by Alasaad et al. [23]

\section{OLADRB1 microsatellite genotyping}

In an analysis of a microsatellite locus (OLADRB1) linked to the MHC DRB1 gene of Iberian ibex, Alasaad et al. [23] detected strong linkage disequilibrium between these loci. The allele length polymorphism at OLADRB1 was unambiguously linked to a particular DRB1 allele. This allowed the development of a DRBSTR matching method for the simple and relatively inexpensive protocol for MHC DRB1 genotyping. In our present study we used the same methodology to identify the OLADRB1 microsatellite linked to the newly discovered MHC DRB1 haplotype.

The PCR experiments were conducted using $3 \mu \mathrm{L}$ gDNA, $0.1 \mu \mathrm{M}$ of each OLADRB1 primers [29, 32], 0 . $2 \mu \mathrm{M}$ dNTP's, $1 \times$ buffer (QIAGEN), and $0.15 \mu \mathrm{L}$ Taq Polymerase $(5 \mathrm{U} / \mu \mathrm{L})$ (Hot-Start Taq DNA polymerase, QIAGEN) in a final volume of $15 \mu \mathrm{L}$. PCR was performed with fluorescence-conjugated forward primer using 6-carboxyfluorescein (6-FAM). After an initial denaturation step of $15 \mathrm{~min}$ at $95{ }^{\circ} \mathrm{C}$, the samples were processed through 35 cycles consisting of $30 \mathrm{~s}$ at $94{ }^{\circ} \mathrm{C}$,
$45 \mathrm{~s}$ at $60{ }^{\circ} \mathrm{C}$ and $90 \mathrm{~s}$ at $72{ }^{\circ} \mathrm{C}$, followed by a terminal elongation step of $7 \mathrm{~min}$ at $72{ }^{\circ} \mathrm{C}$.

Using 96-well plates, aliquots of $12 \mu \mathrm{L}$ of formamide with LIZ size standard ( $5 \mu \mathrm{l} \mathrm{LIZ-500} \mathrm{and} 500 \mu \mathrm{l} \mathrm{Hi-Di}$ formamide, Applied Biosystems, Foster City, California) and $1 \mu \mathrm{L}$ PCR product were analyzed on an ABI Prism 310 Genetic Analyzer (Applied Biosystems, Foster City, California). Allele sizes and genotypes were determined using GeneMapper 3.7 (Applied Biosystems) followed by manual proofreading.

\section{Molecular analyses}

Genbank blast searches matching up to a $96 \%$ identity were downloaded and included in the phylogenetic analyses. For comparative purposes all the sequences used in the Amills et al. [22] study were included. Sequences were aligned in Seaview v.4.2.11 [33] with ClustalW2 [34] default settings. The best substitution model for the Bayesian inference (BI) analysis was identified using the Bayesian information criterion (BIC) in jModeltest v.2 [35]. MrBayes v.3.2.6 [36] was run with default priors 
and Markov chain settings, as well as with random starting trees. Runs consisted of four chains of 20,000,000 generations that were sampled every 10,000 generations. After a number of generations, a plateau with $10 \%$ of the trees derived from the analyses discarded during the burn in was reached. A maximum likelihood (ML) approach executed with the software RAxML v7.0.4 [37] with the default settings was used to estimate the phylogenetic relationships among haplotypes for each locus. The best-fitting model for the phylogenetic analyses was the $\mathrm{HKY}+\mathrm{G} \quad(-\operatorname{lnL}=1792.68621, \quad \mathrm{BIC}=4112.534648)$. All the analyses were performed through the CIPRES platform [38], Additional file 1.

\section{Graphical image}

The map used in Fig. 1 was prepared using political boundaries and USGS data distributed by the Land Processes Distributed Active Archive Center (LP DAAC), located at USGS/EROS, Sioux Falls, SD. http://lpdaac. usgs.gov [39]. Copyright permissions for these sources are not required.

\section{Results and discussion}

We increased the sampling size to include previously unstudied Iberian ibex populations and discovered a new allele of the MHC DRB1 locus in four isolated populations in southern Spain, namely in Sierras de Cazorla, Segura and las Villas Natural Park (SCSVNP), El Hosquillo in Serranía de Cuenca Natural Park, Sierra del Mencal, and Cabañeros National Park (Table 2 \& Fig. 1). The new allele was denominated MHC DRB1*7 (Genbank accession KY597633). This finding demonstrates greater genetic diversity in this species than previously thought (only five persistent alleles, [22, 23]), which supports our hypothesis that small and isolated wild animal populations hide unexpected genetic diversity.

The aminoacid reading frame was the same for Capra pyrenaica DRB1.3 (AF461694), DRB1.6 (AY351788) and AB008359 (C. hircus). As expected given the similarity of the data, the phylogenetic analyses recovered a tree topology and paraphyly of the DRB1 haplotypes similar to the findings of Amills et al. [22]. The new haplotype Capy-DRB1*7 is grouped with C. hircus and C. pyrenaica DRB1*3 and BRB1*6. The node support was weaker in the ML than in the Bayesian analyses but the Bayesian posterior probability for this former clade was supported above 0.95. Together, this suggests good confidence in the grouping of DRB1*7 (Fig. 2).

The ibex populations in El Hosquillo and Cabañeros National Park were originally founded with a limited number of ibexes translocated from SCSVNP; Sierra del Mencal is a small mountain range $25 \mathrm{~km}$ from the southwestern border of SCSVNP but within the dispersal range of the species. All in all, this distribution suggests that the new discovered allele originated from SCSVNP. In the late 1980s, the Iberian ibex in SCSVNP suffered a catastrophic scabies outbreak and only a few hundred individuals survived from the pre-epidemic herd of over 12,000 individuals [40].

The new discovered allele is not expected to contribute to greater fitness in C. $p$. pyrenaica since it codes for the same protein as the existing MHC DRB1*6. Further sequences of the whole gene are still needed to make a full comparison between these two alleles (MHC DRB1*6 and MHC DRB1"7). The new allele, MHC DRB1*7, is identical to one reported in the domestic Saanen goat (C. aegagrus hircus) (Genbank accession number U00200; [41]). Trans-species alleles for the MHC DRB1 gene have already been reported in closely related mountain ungulates such as the southern and northern chamois (Rupicapra pyrenaica and R. rupicapra, respectively) [42]. Two hypotheses could explain this similarity: I: the result of ancient polymorphism maintained by balancing selection, or II: introgression from domestic goats through hybridization [26]. Our data seem to support the introgression hypothesis since the newly discovered allele was only found in a single isolated population (and a few herds derived from it), and because hybridization between Iberian ibex and domestic goat has already been reported in the region [24]. Introgression and hybridization reports are not uncommon in Caprine species. Recent work on alpine ibex DRB genes found them to be homozygous for the goattype DRB exon 2 alleles and almost identical to domestic goats (Capra aegagrus hircus). The authors of this study [43] conclude that the MHC is susceptible to adaptive introgression between species through balancing selection [44] and that introgression may well be an underappreciated mechanism generating extraordinary genetic diversity at the MHC [45]. In a few cases, hybrids between Capra ibex ibex and domestic goats have been reported in captivity [46] and genetically proved in the wild [47]. Hybridization between Iberian ibex (Capra pyrenaica) and domestic goats in the wild has also been reported [24].

Ovine and caprine populations have a great socioeconomic importance in this area; censuses in SCSVNP have estimated that there are 85,100 sheep and 13,200 goats within its boundaries, of which with c. $60 \%$ is devoted to pasture (Data from Consejería de Agricultura, Pesca y Desarrollo Rural). Today, the traditional seasonal migration of cattle by farmers is now in decline but caprine production is on the increase, mainly in the southern sector of the park. These circumstances favour contact between Iberian ibex and domestic goats.

Nevertheless, Quemere et al. [8] suggest that genetic drift is the main contemporary evolutionary force shaping immunogenetic variation within populations. These authors, in contrast to the classical view, found that some genes involved in microparasite recognition continue to evolve dynamically in roe deer (Capreolus capreolus) in 


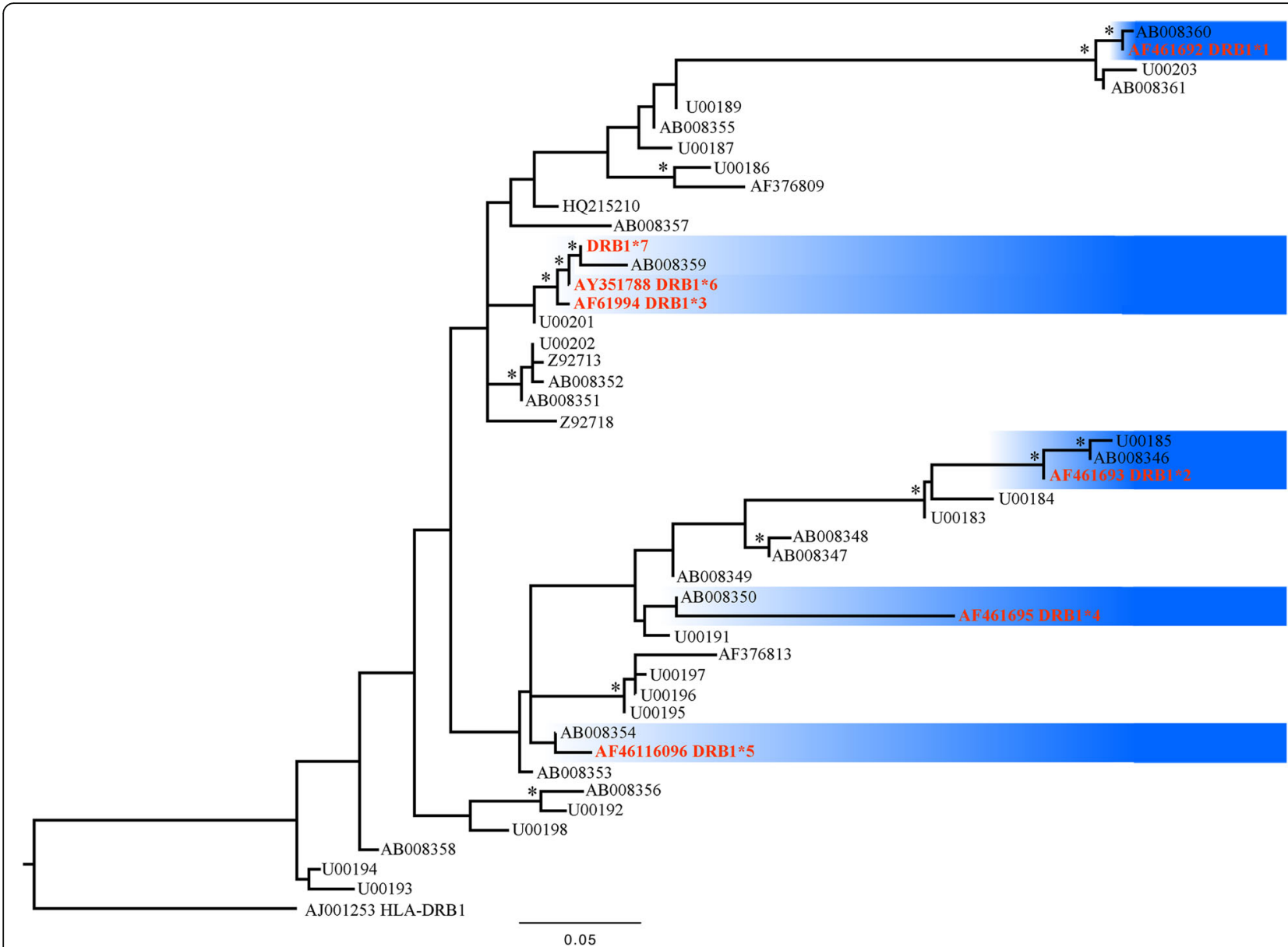

Fig. 2 Best maximum likelihood (ML) tree for the MHC (257 bp) gene fragment. Capra pyrenaica haplotypes are marked in red and their clades in blue. An asterisk (*) on nodes denotes posterior probabilities (Pp) recovered from the Bayesian analysis and bootstrap support from the ML bipartition tree $(\geq 95 \%)$, respectively

response to pathogen-mediated positive selection. In fact, high recombination rates are suspected to occur in a number of ungulate species [7]. On the other hand, low MHC variation does not seem to be the cause of disease susceptibility and demographic decline in bighorn sheep (Ovis canadensis) and, moreover, this variation is thought to be functionally significant and maintained by balancing selection [48].

The MHC DRB1*1 was the most frequent (35.23\%) allele in the studied populations, followed by MHC DRB1*2 (24.62\%), MHC DRB1*5 (17.05\%), MHC DRB1*3 (9.47\%), MHC DRB1*7 (7.2\%) and MHC DRB1*6 (6.44\%). MHC DRB1 alleles were distributed randomly without any clear longitudinal or latitudinal patterns. MHC DRB class II diversity in wild ungulates decreases with increasing latitude, possibly as a result of lower parasite diversity at higher latitudes [9]. However, this does not seem to be the case of the Iberian ibex, most likley due to the relatively small distribution area of this species.
Analysis of microsatellite locus (OLADRB1) linked to the new MHC DRB1*7 gene detected absolute linkage disequilibrium between these loci. The allele OLADRB1 with $187 \mathrm{bp}$ length was unambiguously linked to the MHC DRB1*7 allele. This allowed us to develop a DRB-STR matching method for the newly discovered MHC allele.

\section{Conclusions}

In this paper we report hidden genetic diversity in light of our discovery of a new MHC DRB1 allele in the genetically poor Iberian ibex. This newly identified allele is putatively the result of introgression from domestic goats and can be identified through a simple, newly developed protocol based on OLADRB1 microsatellite analysis. This new discovery is critical for the conservation biology of the Iberian ibex since it directly affects the identification of the units of species that should be managed and conserved separately (Evolutionarily Significant Units: ESU). 


\section{Additional file}

Additional file 1: Nexus file of the phylogenetic alignment. (ZIP $1 \mathrm{~kb}$ )

\section{Abbreviations}

bp: Base pair; ESUs: Evolutionarily Significant Units; MHC: Major

Histocompatibility Complex; STR: Short Tandem Repeat

\section{Acknowledgements}

We would like to thank Apolo Sánchez, Elías Martínez, Isidro Puga, Pepe López, Francisco Casado and Antonio Rodríguez for their assistance with the fieldwork in Sierra Nevada. We are also grateful to Miguel Ángel Habela, Santiago Lavín, Pelayo Acevedo, Eularico Fernández, Francisco Martínez, Juan Monje, Jaime Medina, Juan Antonio Funes, Antonio Serrano, Pepe Madrazo, Luis Alfonso Sarmiento and José Luis Chao for providing Iberian ibex samples.

\section{Funding}

This study was partially funded by the Consejería de Medio Ambiente of the Junta de Andalucía (projects 173/2009/M/00 and 03/15/M/00) and the Ministerio de Economía y Competitividad of the Spanish Government (projects CGL2012-40043- C02-01, CGL2012-40043-C02-02 and CGL201680543-P). The funding bodies did not contribute to the design of the study or collection, analysis and interpretation of data, or to the writing of the manuscript.

\section{Availability of data and materials}

All the relevant information supporting the results of this article is included within the article and its additional files.

\section{Authors' contributions}

SAA, PF, FJCM, JMP, LR and JEG initiated the project. PF, PP, FJCM, GM, JRLO, $A R, J E$, and JEG performed the experiments. SAA, MJJ, ARMM and MP analyzed the data. SAA, MJJ, ARMM, PF, PP, MP, FJCM, GM, JRLO, AR, JE, JMP, RCS, LR and JEG wrote the manuscript. All the authors read and approved the final manuscript.

\section{Ethics approval}

The samples consisted of tissue (small biopsy from the ears) obtained from deceased legally hunted animals, or from animals culled by park rangers as part of wildlife management plans aimed especially at controlling ungulate density and preventing outbreaks of diseases. Thus, no animal ethical permits were necessary since no live ibex were handled during this study. This study was approved by the Spanish Ministry of Agriculture, Fishery and Environment of the Andalusian government (Junta de Andalucía, Spain). Sampling procedures were issued as part of the application for permits for the fieldwork, which did not affect any endangered or protected species.

\section{Competing interests}

The authors declare that they have no competing interests.

\section{Publisher's Note}

Springer Nature remains neutral with regard to jurisdictional claims in published maps and institutional affiliations.

\section{Author details}

Estación Biológica de Doñana, Consejo Superior de Investigaciones Científicas (CSIC), Avda. Américo Vespucio s/n, 41092 Sevilla, Spain. ${ }^{2}$ Institute of Evolutionary Biology and Environmental Studies (IEU), University of Zurich, Winterthurerstrasse 190, Zurich, Switzerland. ${ }^{3} \mathrm{CIBIO} / \mathrm{InBIO}$ (Centro de Investigação em Biodiversidade e Recursos Genéticos), Universidade do Porto, Campus Agrario De Vairão, 4485-661 Vairão, Portugal. ${ }^{4}$ Dipartimento di Scienze Veterinarie, Universita` degli Studi di Torino, Grugliasco, Italy. ${ }^{5}$ Agencia de Medio Ambiente y Agua, E-41092 Sevilla, Isla de la Cartuja, Spain. ${ }^{6}$ Parque Natural Sierras de Cazorla, Segura y Las Villas, Martínez Falero11, E-23470 Cazorla, Jaén, Spain. ${ }^{7}$ Espacio Natural Sierra Nevada, Carretera Antigua de Sierra Nevada, Km 7, E-18071 Pinos Genil, Granada, Spain. ${ }^{8}$ Servei d'Ecopatologia de Fauna Salvatge (SEFAS), Departament de Medicina i Cirurgia Animals, Universitat Autònoma de Barcelona (UAB),
E-08193 Bellaterra, Barcelona, Spain. 'Departamento de Biología Animal, Biología Vegetal y Ecología, Universidad de Jaén, Campus Las Lagunillas, s.n., E-23071 Jaén, Spain.

Received: 28 December 2017 Accepted: 30 April 2018

Published online: 08 May 2018

\section{References}

1. Carvalho DC, Denise Oliveira AA, Behegaray LB, Torres RA. Hidden genetic diversity and distinct evolutionarily significant units in an commercially important Neotropical apex predator, the catfish Pseudoplatystoma corruscans. Conserv Genet. 2012;13:1671-5.

2. Frankham R. Challenges and opportunities of genetic approaches to biological conservation. Biol Conserv. 2010;143:1919-27.

3. Bernatchez $L$, Landry C. MHC studies in nonmodel vertebrates: what have we learned about natural selection in 15 years. J Evol Biol. 2003;16:363-77.

4. Shafer ABA, Fan CW, Cote SD, Coltman DW. (Lack of) genetic diversity in immune genes predates glacial isolation in the north American mountain goat (Oreamnos americanus). J Hered. 2012;103:371-9.

5. Robinson J, Waller MJ, Parham P, de Groot N, Bontrop R, Kennedy LJ, Stoehr $P$, Marsh SGE. IMGT/HLA and IMGT/MHC: sequence databases for the study of the major histocompatibility complex. Nucleic Acids Res. 2003:31:311-4.

6. Klein J. The natural history of the major histocompatibility complex. New York: John Wiley and Sons; 1986.

7. Schaschl H, Wandeler P, Suchentrunk F, Obexer-Ruff G, Goodman SJ. Selection and recombination drive the evolution of MHC class II DRB diversity in ungulates. Heredity. 2006;97:427-37.

8. Quemere E, Galan M, Cosson JF, Klein F, Aulagnier S, Gilot-Fromont E, Merlet J, Bonhomme M, Hewison AJM, Charbonnel N. Immunogenetic heterogeneity in a widespread ungulate: the European roe deer (Capreolus capreolus). Mol Ecol. 2015;24:3873-87.

9. Mainguy J, Worley K, Côté SD, Coltman DW. Low MHC DRB class II diversity in the mountain goat: past bottlenecks and possible role of pathogens and parasites. Conserv Genet. 2007;8:885-91

10. Yuhki N, O'Brien SJ. DNA variation of the mammalian majo histocompatibility complex reflects genomic diversity and population history. Proc Natl Acad Sci U S A. 1990:87:836-40.

11. O'Brien SJ, Wildt DE, Bush M, Caro TM, FitzGibbon C, Aggundey I, et al. East African cheetahs: evidence for two population bottlenecks? Proc Natl Acad Sci U S A. 1987:84:508-11.

12. Watkins DI, Garber TL, Chen ZW, Toukatly G, Hughes AL, Letvin NL. Unusually limited nucleotide sequence variation of the expressed major histocompatibility complex class I genes of a new world primate species (Saguinus oedipus). Immunogenetics. 1991;33:79-89.

13. Ellegren $H$, Hartman $G$, Johansson M, Andersson L. Major histocompatibility complex monomorphism and low levels of DNA fingerprinting variability in a reintroduced and rapidly expanding population of beavers. Proc Natl Acad Sci U S A. 1993:90:8150-3.

14. Mikko S, Røed K, Schmutz S, Andersson L. Monomorph- ism and polymorphism at Mhc DRB loci in domestic and wild ruminants. Immunol Rev. 1999;167:169-78.

15. Hedrick PW, Parker KM, Gutierrez-Espeleta GA, Rattink A, Lievers K. Major histocompatibility complex variation in the Arabian oryx. Evolution. 2000;54:2145-51.

16. Morris K, Austin JJ, Belov K. Low major histocompatibility complex diversity in the Tasmanian devil predates European settlement and may explain susceptibility to disease epidemics. Biol. Lett. 2013;9:2012.

17. Sommer S, Schwab D, Ganzhorn JU. MHC diversity of endemic Malagasy rodents in relation to geographic range and social system. Behav Ecol Sociobiol. 2002;51:214-21.

18. Angelone-Alasaad S, Jowers JM, Panadero R, Pérez-Creo A, Pajares G, Díez-Baños P, Soriguer RC, Morrondo P. First report of Setaria tundra in roe deer (Capreolus capreolus) from the Iberian peninsula inferred from molecular data: epidemiological implications. Parasit Vectors. 2016;9:e521.

19. Cabrera A. The subspecies of Spanish ibex. Proc Zool Soc London. 1911; 1911:963-7.

20. Cabrera A. Fauna ibérica. Mamíferos. Madrid: Museo Nacional de Ciencias Naturales; 1914

21. Manceau, V., 1997, Polymorphisme des séquences d'ADN mitochondrial dans le genre Capra. Application à la conservation du bouquetin des Pyrénées (C. pyrenaica pyrenaica). Doctoral Thesis, University Joseph Fourier. 
22. Amills M, Jiménez N, Jordana J, Riccardi A, Fernández-Arias A, Guiral J, Bouzat JL, Folch J, Sánchez A. Low diversity in the major histocompatibility complex class II DRB1 gene of the Spanish ibex, Capra pyrenaica. Heredity. 2004;93:266-72

23. Alasaad S, Biebach I, Grossen C, Soriguer RC, Pérez JM, Keller LF. DRB-STR matching method for Iberian and alpine ibex MHC haplotyping. Eur J Wildl Res. 2012;58:743-8.

24. Alasaad S, Fickel J, Rossi L, Sarasa M, Soriguer RC. Applicability of major histocompatibility complex DRB1 alleles as markers to detect vertebrate hybridization: a case study from Iberian ibex $\mathrm{x}$ domestic goat in southern Spain. Acta Vet Scand. 2012:54:e56.

25. Pérez JM, Granados JE, Soriguer RC, Fandos P, Márquez FJ, Crampe JP. Distribution, status and conservation problems of the Spanish ibex, Capra pyrenaica (Mammalia: Artiodactyla). Mammal Rev. 2002;32:26-39.

26. Angelone-Alasaad S, Biebach I, Pérez JM, Soriguer RC. Granados JE. Molecular analyses reveal unexpected genetic structure in Iberian ibex populations. PLoS One. 2017;12:e0170827.

27. Doxiadis GG, de Groot N, Claas FHJ, Doxiadis IIN, van Rood JJ, Bontrop RE. A highly divergent microsatellite facilitating fast and accurate DRB haplotyping in humans and rhesus macaques. Proc Natl Acad Sci U S A. 2007;104:8907-12.

28. Schaschl H, Goodman SJ, Suchentrunk F. Sequence analysis of the MHC class II DRB alleles in alpine chamois (Rupicapra r. rupicapra). Dev Comp Immunol. 2004;28:265-77.

29. Schwaiger FW, Buitkamp J, Weyers E, Epplen JT. Typing of artiodactyl MHCDRB genes with the help of intronic simple repeated DRD-sequences. Mol Ecol. 1993;2:55-9.

30. Hall TA. BioEdit: a user-friendly biological sequence alignment editor and analysis program for windows 95/98/NT. Nucleic Acids Symp Ser. 1999:41:95-8

31. Stephens M, Smith NJ, Donnelly P. A new statistical method for haplotype reconstruction from population data. Am J Hum Genet. 2001;68:978-89.

32. Paterson S. Evidence for balancing selection at the major histocompatibility complex in a free-living ruminant. J Hered. 1998:89:289-94.

33. Gouy M, Guindon S, Gascuel O. SeaView version 4: A multiplatform graphical user interface for sequence alignment and phylogenetic tree building. Mol Phylogenet Evol. 2010;27:221.

34. Larkin MA, Backshields G, Brown NP, Chenna R, McGettigan PA, McWilliam $\mathrm{H}$, et al. Clustal W and Clustal X version 2.0. Bioinfomatics Application Note. 2007;23:2947.

35. Posada D. jModelTest: phylogenetic model averaging. Mol Biol Evol. 2008; 25:1253.

36. Ronquist F, Huelsenbeck JP. MRBAYES 3: Bayesian phylogenetic inference under mixed models. Bioinformatics. 2003;19:1572.

37. Silvestro D, Michalak I. A user friendly graphical front-end for phylogenetic analyses using RAxML (Stamatakis, 2006). Org Divers Evol. 2010;12:335.

38. Miller MA, Pfeiffer W, Schwartz T. Creating the CIPRES Science Gateway for inference of large phylogenetic trees. New Orleans: Proceedings of the Gateway Computing Environments Workshop (GCE); 2010. p.1.

39. US Geological Survey. Land Processes Distributed Active Archive Center (LP DAAC). USGS/EROS, Sioux Falls, SD.

40. Fandos P. La Cabra montés (Capra pyrenaica) en el Parque natural de las sierras de Cazorla, Segura y las Villas. Madrid: Ministerio de Agricultura Pesca y Alimentación, ICONA; 1991.

41. Schwaiger FW, Weyers E, Epplen C, et al. The paradox of MHC-DRB exon/ intron evolution: $a$-helix and $\beta$-sheet encoding regions diverge while hypervariable intronic simple repeats coevolve with $\beta$-sheet codons. J Mol Evol. 1993;37:260.

42. Cavallero S, Marco I, Lavín S, D’Amelio S, López-Olvera JR. Polymorphism at MHC class II DRB1 exon 2 locus in Pyrenean chamois (Rupicapra pyrenaica pyrenaica). Infect Genet Evol. 2012;12:1020-6.

43. Grossen C, Keller L, Biebach I, International Goat Genome Consortium, Croll D. Introgression from domestic goat generated variation at the Major Histocompatibility Complex of Alpine ibex. PLoS Genet. 2014;10:e1004438.

44. Wegner KM, Eizaguirre C. New(t)s and views from hybridizing MHC genes: introgression rather than trans-species polymorphism may shape allelic repertoires. Mol Ecol. 2012;21:779-81. https://doi.org/10.1111/j.1365-294X. 2011.05401.x.

45. Hedrick PW. Adaptive introgression in animals: examples and comparison to new mutation and standing variation as sources of adaptive variation. Mol Ecol. 2013;22:4606-18. https://doi.org/10.1111/mec.12415.
46. Stüwe M, Grodinsky C. Reproductive biology of captive alpine ibex (Capra ibex ibex L.). Zoo Biol. 1987;6:331-9. https://doi.org/10.1002/zoo.1430060407.

47. Giacometti M, Roganti R, De Tann M, Stahlberger-Saitbekova N, Obexer-Ruff G. Alpine ibex Capra ibex ibex $x$ domestic goat C. Aegagrus domestica hybrids in a restricted area of southern Switzerland. Wild Biol. 2004;10:137-43.

48. Gutiérrez-Espeleta GA, Hedrick PW, Kalinowski ST, Garrigan D, Boyce WM. Is the decline of desert bighorn sheep from infectious disease the result of low MHC variation? Heredity. 2001;86:439-50.

\section{Ready to submit your research? Choose BMC and benefit from:}

- fast, convenient online submission

- thorough peer review by experienced researchers in your field

- rapid publication on acceptance

- support for research data, including large and complex data types

- gold Open Access which fosters wider collaboration and increased citations

- maximum visibility for your research: over $100 \mathrm{M}$ website views per year

At BMC, research is always in progress.

Learn more biomedcentral.com/submissions 